\title{
JPEB
}

Jurnal Penelitian Ekonomi dan Bisnis, 4 (2), 2019, Hal: 166-173

http://www.jpeb.dinus.ac.id

\section{FAKTOR PENENTU PERTUMBUHAN USAHA PERAK DI KOTA GEDE YOGYAKARTA}

\author{
Airin Saraswati Damanik ${ }^{1}$ dan Amir Hidayatulloh ${ }^{2 *}$ \\ ${ }^{1,2}$ Program Studi Akuntansi, Fakultas Ekonomik dan Bisnis, Universitas Ahmad Dahlan \\ Jalan Kapas Nomor 9 Semaki, Umbulharjo, Kota Yogyakarta, Indonesia \\ *Corresponding Email : amir.hidayatulloh@act.uad.ac.id
}

Diterima: Mei 2019; Direvisi: Agustus 2019; Dipublikasikan: September 2019

\begin{abstract}
This type of research is quantitative research. The population this study were MSMEs in the Special Region of Yogyakarta. The sampling technique of this study used purposive sampling with criteria of (1) MSMEs in Kotagede Subdistrict, and (2) MSMEs engaged in silver handicrafts. The data collection technique of this study used the survey method a questionnaire. Questionnaires were given directly to respondents who met the criteria. Respondents in the study amounted to 33 respondents. The data analysis technique of this study uses multiple linear regression analysis. This research obtained the result that the business growth of MSMEs was influenced by nature of entrepreneurship and business environment. However, business capital does not affect business growth.
\end{abstract}

Keywords: Entrepreneurial Characteristics; Business Environment; Venture Capital; Business Growth; MSMES

\begin{abstract}
ABSTRAK
Jenis penelitian ini adalah penelitian kuantitatif. Populasi dalam penelitian ini adalah pelaku UMKM di Daerah Istimewa Yogyakarta. Teknik pengambilan sampel penelitian ini menggunakan purposive sampling, dengan kriteria (1) pelaku UMKM yang berada di Kecamatan Kotagede, dan (2) UMKM yang bergerak di bidang kerajinan perak. Teknik pengumpulan data penelitian ini menggunakan metode survei dengan kuesioner. Kuesioner diberikan secara langsung kepada responden yang memenuhi kriteria. Responden dalam penelitian berjumlah 33 responden. Teknik analisis data penelitian ini menggunakan analisis regresi linear berganda. Penelitian ini memperoleh hasil bahwa pertumbuhan usaha UMKM dipengaruhi oleh karatersitik wirausaha dan lingkungan bisnis. Akan tetapi, modal usaha tidak berpengaruh terhadap pertumbuhan usaha.
\end{abstract}

Kata Kunci: Karateristik Wirausah; Lingkungan Bisnis; Modal Usaha; Pertumbuhan Usaha; UMKM 



\section{PENDAHULUAN}

Salah satu sumber penting di Indonesia adalah keberadaan Usaha Mikro Kecil dan Menengah. Menurut kementerian koperasi dan UMKM tahun 2017, devisa Negara mengalami peningkatan dari para pelaku UMKM dan penerimaan dari UMKM mencapai Rp88,45 miliar. Jumlah ini mengalami peningkatan delapan kali lipat dari tahun sebelumnya (Dwi, 2017). Sehingga berdasarkan data ini, pemerintah harus lebih serius lagi memperhatikan perkembangan UMKM di Indonesia. Hal ini karena keberadaan UMKM akan membantu pemerintah dalam menanggulangi masalah ekonomi Indonesia.

Menurut (Primus, 2017), pada tahun 2017 pemerintah menambah dana bergulir untuk pelaku UMKM sebesar Rp1,5 triliun. Dana ini disalurkan melalui Lembaga Pengelola Dana Bergulir (LPDB) Kementerian Koperasi dan UKM (KUMKM). Tujuan penambahan dana bergulir ini bertujuan untuk membidik 120.292 UMKM mitra di seluruh Indonesia melalui 586 mitra yang terdiri dari koperasi dan non koperasi.

Menurut data yang disajikan pada (Tempo.co, 2015), Kotagede Daerah Istimewa Yogyakarta merupakan salah satu pusat pengrajin emas, perak, dan kuningan. Produk buatan tangan ini berpotensi dijual hingga mancanegara dan menambah penghasilan di Kotagede. Namun, di sisi lain pelaku usaha kesulitan dalam melakukan ekspansi usaha, memperoleh tambahan modal, serta melemahnya nilai tukar rupiah pada dolar Amerika dan Euro membuat biaya omset perajin perak di Kotagede mengalami penurunan. Tingginya nilai tukar Euro ini juga membuat biaya produksi ikut meningkat.

Lebih lanjut (Tempo.co, 2015), masalah yang dihadap para pengrajin perak ini sangat serius. Hal ini karena bahan baku perak yang semakin mahal membuat pelaku UMKM terbatas memiliki bahan baku. Sehingga, pada kasus ini laporan keuangan memiliki peran penting. Hal ini karena laporan keuangan dapat mempermudah pelaku UMKM untuk memperoleh modal tambahan.

Beberapa penelitian sudah menguji faktor yang menentukan pertumbuhan usaha, seperti (Kurniawan \& Rinofah, 2016); (Setyawati, Nugraha, \& Ainuddin, 2013); (Purwanti, 2012); (Inggarwati \& Kaudin, 2010). Beberapa penelitian terdahulu menemukan hasil bahwa karateristik kewairausahaan pemilik usaha, kondisi lingkungan bisnis, serta modal usaha berpengaruh terhadap pertumbuhan usaha. Hasil yang sama juga diperoleh (Pamungkas \& Hidayatulloh, 2019) yang menyatakan bahwa modal usaha dan karateristik entrepreneur berpengaruh terhadap perkembangan usaha. Dari uraian sebelumnya, maka penelitian ini bertujuan untuk menganalisis pengaruh karateristik wirausaha, modal usaha, serta lingkungan bisnis pada pertumbuhan usaha.

\section{TINJAUAN PUSTAKA}

\section{Usaha Mikro Kecil dan Menengah}

Usaha Mikro Kecil dan Menengah (UMKM) secara umum adalah kegiatan bisnis yang dimiliki oleh perseorangan. Kriteria usaha mikro, usaha kecil, dan usaha menengah dijelaskan pada (Undang-Undang Nomor 20, 2008). Kriteria usaha mikro adalah usaha yang memiliki kekayaan bersih paling banyak Rp 50.000.000 tidak termasuk tanah dan bangunan, dan memiliki hasil penjualan tahunan sebanyak Rp 300.000.000 Kriteria usaha kecil adalah usaha yang memiliki kekayaan bersih lebih dari Rp 50.000.000 sampai dengan paling banyak Rp 500.000 .000 tidak termasuk tanah dan bangunan, serta memiliki hasil penjualan tahunan lebih dari Rp 300.000.000 sampai dengan paling banyak Rp 2.500.000.000. Sedangkan, kriteria usaha menengah adalah usaha yang memiliki kekayaan bersih lebih dari $\mathrm{Rp} 500.000 .000$ sampai dengan paling banyak Rp 10.000.000.000, serta memiliki hasil penjualan tahunan lebih dari $\operatorname{Rp} 2.500 .000 .000$ sampai dengan $\operatorname{Rp} 5.000 .000 .000$. 
Airin Saraswati Damanik dan Amir Hidayatulloh : Faktor Penentu Pertumbuhan Usaha Perak di Kotagede Yogyakarta

\section{Karakteristik Wirausaha}

Karakteristik kewirausahaan merupakan kualitas atau sifat yang tetap terus menerus dan kekal yang dapat dijadikan ciri untuk mengidentifikasikan seorang pribadi, suatu objek, suatu kejadian, integrasi atau sintesis dari sifat-sifat individual dalam bentuk suatu atau kesatuan dan kepribadian individu, dipertimbangakan dari titik pandangan etis dan moral (Wiratmo, 2001). Lebih lanjut (Wiratmo, 2001) menyatakan karateristik wirausahawan meliputi keinginan untuk bertanggungjawab, persepsi pada kemungkinan berhasil, rangsangan oleh umpan balik, keterampilan dalam pengorganisasian, serta sikap pada uang.Menurut (Hantoro, 2005), seorang wirausahawan harus paling tidak memiliki kriteria, yaitu memiliki kemauan keras dan pantang menyerah, jujur dan bertanggung jawab, memiliki keyankinan yang kuat atas kekuatan pribadi, memiliki ketahanan fisik dan mental, bekerja keras, tekun dan ulet, serta memiliki pemikiran yang kreatif.

\section{Lingkungan Bisnis}

Lingkungan bisnis merupakan suatu kekuatan, suatu kondisi, suatu keadaan, suatu peristiwa yang saling berhubungan. Organisasi atau perusahaan memiliki atau tidak memiliki kemampuan untuk mengendalikannya. Sedangkan lingkungan internal, organisasi atau perusahaan memiliki kemampuan untuk mengendalikannya (Jatmiko, 2004).

\section{Modal usaha}

Salah satu faktor yang mendukung berjalannya usaha adalah modal. Modal dalam dunia bisnis keberadaanya menjadi pondasi awal bisnis yang akan dibangun (Riyanto, 2001). Lebih lanjut (Riyanto, 2001), modal yang dibutuhkan dalam menjalankan suatu bisnis antara lain tekat, keberanian, pengalaman, pengetahuan, jejaring, maupun modal yang berupa uang. Akan tatapi, permasalahan yang dihadapi individu saat menjalankan usaha adalah mendapatkan modal uang. Modal dikategorikan menjadi tiga kategori yaitu modal investasi, modal kerja, serta modal operasional. Modal investasi merupakan modal yang harus dikeluarkan, dan biasanya dipakai dalam jangka waktu panjang. Modal kerja adalah modal yang dikeluarkan untuk membuat atau membeli barang dagangan. Sedangkan, modal operasional adalah modal yang harus dimiliki untuk dapat melakukan proses produksi.

Berdasarkan latar belakang dan tinjauan pustaka yang telah diuraikan sebelumnya, maka rerangka penelitian ini dapat digambarkan sebagai berikut.

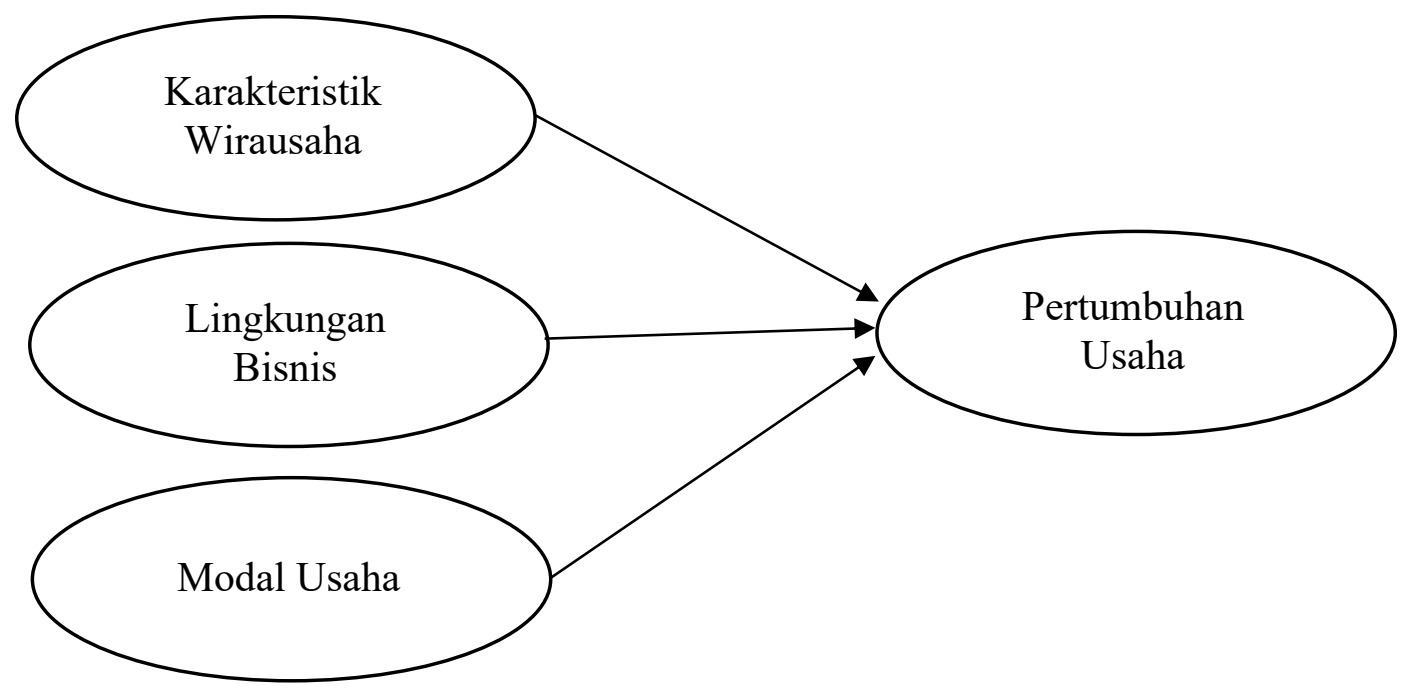

Gambar 1. Rerangka Penelitian 


\section{Pengaruh Karateristik Wirausaha Terhadap Pertumbuhan Usaha}

Karateristik seorang wirausaha antara lain percaya diri, berorientasi pada tugas dan hasil, memiliki jiwa kepemimpinan, berani mengambil risiko, kreatif, serta dapat memanfaatkan waktu. Karakteristik wirausaha menjadi sebuah pondasi untuk memulai suatu usaha. Hal ini karena wirausahaan harus memiliki karakteristik yang kuat untuk menghadapi setiap tantangan dan resiko yang akan dihadapi saat menjalankan usaha. Jadi, ketika individu memiliki sebagaian besar dari karakteristik wirausaha, maka semakin besar pula pertumbuhan usaha yang dimiliki (Vries, 1997). Pernyataan ini didukung oleh hasil penelitian (Pamungkas \& Hidayatulloh, 2019); (Purwanti, 2012); (Inggarwati \& Kaudin, 2010), karakteristik wirausaha berpengaruh terhadap pertumbuhan usaha. Oleh karena, hipotesis pertama $\left(\mathrm{H}_{1}\right)$ penelitian ini adalah sebagai berikut:

$\mathrm{H}_{1}$ : karateristik wirausaha berpengaruh terhadap pertumbuhan usaha

\section{Pengaruh Lingkungan Bisnis Terhadap Pertumbuhan Usaha}

Lingkungan bisnis terbagi menjadi dua yaitu lingkungan bisnis eksternal dan lingkungan bisnis internal. Menurut (Muhammad, 2000), jika perusahaan mengusai faktor internal maka perusahaan dapat mengidentifikasi kekuatan dan kelemahannya. (Handoko, 2001) menyatakan bahwa lingkungan eksternal memiliki dua unsur pengaruh yaitu pengaruh secara langsung (lingkungan eksternal mikro) maupun tidak langsung (lingkungan eksternal makro).Lingkungan bisnis merupakan salah satu faktor yang menentukan pertumbuhan usaha. Semakin baik suatu usaha mengenal lingkungan internal dan lingkungan eksternal, maka wirausaha semakin mudah untuk menghadapi tantangan dalam mengembangkan usahanya. Pernyataan ini didukung oleh hasil penelitian (Kurniawan \& Rinofah, 2016), lingkungan bisnis berpengaruh terhadap pertumbuhan usaha. Oleh karena itu, hipotesis kedua $\left(\mathrm{H}_{2}\right)$ penelitian ini adalah sebagai berikut:

$\mathrm{H}_{2}$ : lingkungan bisnis berpengaruh terhadap pertumbuhan usaha

\section{Pengaruh Modal Usaha Terhadap Pertumbuhan Usaha}

Modal usaha merupakan salah satu faktor yang mutlak diperlukan ketika individu melakukan kegiatan usaha. sehingga, saat menjalankan usaha diperlukan sejumlah dana sebagai dasar ukuran finansial atas usaha. Besar kecilnya modal akan memengaruhi perkembangan usaha dalam pencapaian pendapatan (Riyanto, 2001). Modal usaha dapat diperoleh dari modal sendiri, bantuan pemerintah, lembaga keuangan baik bank maupun non bank. Pernyataan ini didukung oleh hasil penelitian (Pamungkas \& Hidayatulloh, 2019); (Purwanti, 2012), modal usaha berpengaruh terhadap pertumbuhan usaha. Oleh karena itu, hipotesis ketiga $\left(\mathrm{H}_{3}\right)$ penelitian ini adalah sebagai berikut:

$\mathrm{H}_{3}$ : modal usaha berpengaruh terhadap pertumbuhan usaha

\section{METODE PENELITIAN}

Jenis data dalam penelitian ini adalah penelitian kuantitatif. Populasi dalam penelitian ini adalah pelaku UMKM di Daerah Istimewa Yogyakarta. Teknik pengambilan sampel dalam penelitian ini menggunakan purposive sampling, dengan kriteria (1) pelaku UMKM yang berada di kecamatan Kotagede, dan (2) UMKM yang bergerak di bidang kerajinan perak. Teknik pengumpulan data penelitian ini menggunakan metode survei dengan kuesioner. Kuesioner diberikan secara langsung kepada responden yang memenuhi kriteria.

Variabel penelitian terdiri dari variabel independen (karakteristik wirausaha, lingkungan bisnis, dan modal usaha) serta variabel dependen (pertumbuhan usaha). Definisi operasional dan pengukuran masing-masing variabel disajikan pada tabel 1. Teknik analisis data dalam penelitian ini menggunakan analisis regresi linear berganda. 
Airin Saraswati Damanik dan Amir Hidayatulloh : Faktor Penentu Pertumbuhan Usaha Perak di Kotagede Yogyakarta

Tabel 1. Definisi Operasional dan Pengukuran Variabel

\begin{tabular}{|c|c|c|c|c|}
\hline Variabel & Definisi & Referensi & Pengukuran & Referensi \\
\hline $\begin{array}{l}\text { Karakteristik } \\
\text { Wirausaha }\end{array}$ & $\begin{array}{l}\text { Pelaku usaha yang } \\
\text { berorientasi pada } \\
\text { tindakan, memiliki } \\
\text { kemampuan untuk } \\
\text { menvisualisasikan } \\
\text { langkah-langkah } \\
\text { dari gagasan } \\
\text { sampai aktualisasi, } \\
\text { menjadi pemikir } \\
\text { dan pelaku, } \\
\text { perencana dan } \\
\text { pekerja, dapat } \\
\text { mentolerir } \\
\text { ambiguitas, } \\
\text { menerima resiko, } \\
\text { dan dapat } \\
\text { memahami dan } \\
\text { mengelola resiko } \\
\text { tersebut. }\end{array}$ & (Vries, 1997) & $\begin{array}{l}\text { Tujuh item } \\
\text { pertanyaan } \\
\text { dengan } \\
\text { menggunakan } \\
\text { skala likert lima } \\
\text { poin. }\end{array}$ & $\begin{array}{l}\text { (Purwanti, } \\
\text { 2012) }\end{array}$ \\
\hline $\begin{array}{l}\text { Lingkungan } \\
\text { Bisnis }\end{array}$ & $\begin{array}{l}\text { Suatu kekuatan, } \\
\text { suatu kondisi, } \\
\text { suatu keadaan, atau } \\
\text { suatu peristiwa } \\
\text { yang saling } \\
\text { berhubungan } \\
\text { dimana perusahaan } \\
\text { mempunyai atau } \\
\text { tidak mempunyai } \\
\text { kemampuan untuk } \\
\text { mengendalikannya. }\end{array}$ & $\begin{array}{l}\text { (Jatmiko, } \\
\text { 2004) }\end{array}$ & $\begin{array}{l}\text { Sebelas item } \\
\text { pertanyaan } \\
\text { dengan } \\
\text { menggunakan } \\
\text { skala likert lima } \\
\text { poin. }\end{array}$ & $\begin{array}{l}\text { (Purwanti, } \\
\text { 2012) }\end{array}$ \\
\hline Modal Usaha & $\begin{array}{l}\text { Barang-barang } \\
\text { atau peralatan yang } \\
\text { digunakan untuk } \\
\text { melakukan proses } \\
\text { produksi. }\end{array}$ & $\begin{array}{l}\text { (Utari \& Dewi, } \\
\text { 2014) }\end{array}$ & $\begin{array}{l}\text { Lima item } \\
\text { pertanyaan } \\
\text { dengan } \\
\text { menggunakan } \\
\text { skala likert lima } \\
\text { poin. }\end{array}$ & $\begin{array}{l}\text { (Purwanti, } \\
\text { 2012) }\end{array}$ \\
\hline $\begin{array}{l}\text { Pertumbuhan } \\
\text { Usaha }\end{array}$ & $\begin{array}{l}\text { Kemampuan } \\
\text { seseorang } \\
\text { pengusaha untuk } \\
\text { mensosialisasikan } \\
\text { dirinya kepada } \\
\text { kebutuhan pangsa } \\
\text { pasar sehingga ada } \\
\text { perbaikan taraf } \\
\text { hidup pada diri }\end{array}$ & $\begin{array}{l}\text { (Purwanti, } \\
\text { 2012) }\end{array}$ & $\begin{array}{l}\text { Lima item } \\
\text { pertanyaan } \\
\text { dengan } \\
\text { menggunakan } \\
\text { skala likert lima } \\
\text { poin. }\end{array}$ & $\begin{array}{l}\text { (Purwanti, } \\
\text { 2012) }\end{array}$ \\
\hline
\end{tabular}




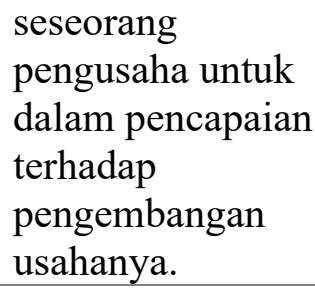

\section{HASIL DAN PEMBAHASAN}

Populasi dalam penelitian ini adalah pelaku UMKM di Daerah Istimewa Yogyakarta. Teknik pengambilan sampel dalam penelitian ini menggunakan purposive sampling, dengan kriteria (1) pelaku UMKM yang berada di kecamatan Kotagede, dan (2) UMKM yang bergerak di bidang kerajinan perak. Teknik pengumpulan data penelitian ini menggunakan metode survei. Dari penyebaran kuesioner, penelitian ini memperoleh 33 responden yang didominasi oleh responden berjenis kelamin laki-laki ( 21 responden), dan 12 responden berjenis kelamin perempuan. Tingkat pendidikan responden didominasi oleh SMA (25 responden), SMP (6 responden) dan strata satu ( 2 responden).

Pengujian hipotesis dalam penelitian diuji menggunakan analisis regresi linear berganda. Hasil pengujian hipotesis disajikan pada tabel 2.

Tabel 2. Hasil Pengujian Hipotesis

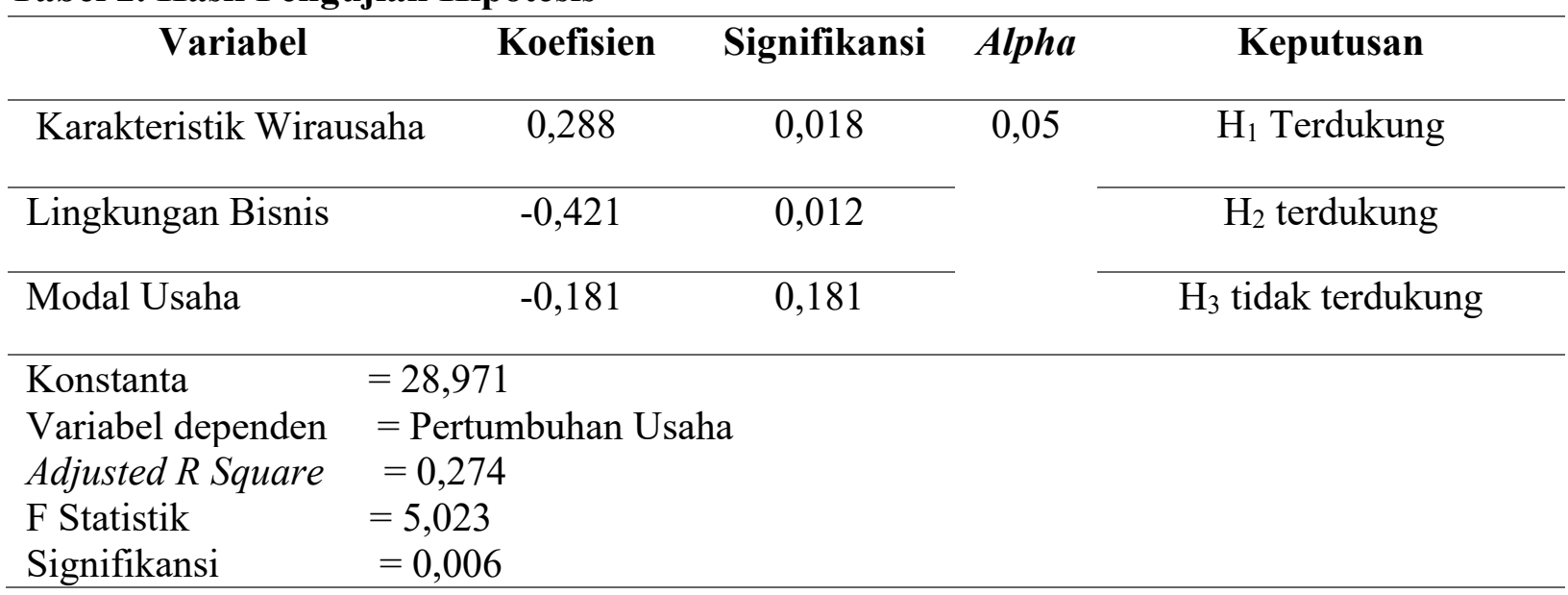

Tabel 2 menunjukan bahwa nilai Adjusted $R$ Square sebesar 0,274. Hal ini berarti bahwa variabel independen (karakteristik wirausaha, lingkungan bisnis, dan modal usaha) dapat menjelaskan variabel dependen (pertumbuhan usaha) sebesar 27,4 persen dan 72,6 persen dijelaskan oleh variabel lain diluar model. Hasil uji F menunjukan nilai signifikasi 0,006 yang lebih kecil dibandingkan 0,05 . Hal ini berarti bahwa minimal ada satu variabel independen (karakteristik wirausaha, lingkungan bisnis, dan modal usaha) yang berpengaruh terhadap pertumbuhan usaha.

Pertumbuhan usaha dipengaruhi oleh karakteristik wirausaha. Hal ini ditunjukan dengan nilai signifikasi $(0,018)$ yang lebih kecil dibandingkan dengan 0,05 . Atau dengan kata lain, hipotesis pertama $\left(\mathrm{H}_{1}\right)$ penelitian ini terdukung. Hal ini berarti bahwa ketika individu memiliki sebagaian karaktersitik wirausaha, maka semakin besar pula pertumbuhan usaha (Vries, 1997). Karakteristik wirausaha minimal yang harus dimiliki adalah kemauan keras dan pantang menyerah, jujur dan bertanggung jawab, memiliki keyakinan yang kuat atas kekuataan pribadi, memiliki ketahanan fisik dan mental, bekerja keras, tekun dan ulet, serta memiliki pemikiran yang kreatif (Hantoro, 2005). Hasil ini didukung oleh hasil penelitian sebelumnya (Pamungkas \& Hidayatulloh, 2019); (Purwanti, 2012); (Inggarwati \& Kaudin, 2010), karakteristik wirausaha berpengaruh terhadap pertumbuhan usaha. 
Airin Saraswati Damanik dan Amir Hidayatulloh : Faktor Penentu Pertumbuhan Usaha Perak di Kotagede Yogyakarta

Faktor lain yang memengaruhi pertumbuhan usaha adalah lingkungan bisnis. Hal ini ditunjukan dengan nilai signifikasi $(0,012)$ yang lebih kecil dibandingkan dengan 0,05 . Atau dengan kata lain, hipotesis kedua $\left(\mathrm{H}_{2}\right)$ penelitian terdukung. Hal ini berarti bahwa semakin baik suatu usaha mengenal lingkungan internal dan lingkungan eksternal, maka wirausaha semakin mudah menghadapi tantangan dalam menjalankan usahanya. Hasil penelitian ini didukung oleh penelitian sebelumnya (Kurniawan \& Rinofah, 2016).

Pertumbuhan usaha tidak dipengaruhi oleh modal usaha. Hal ini ditunjukan dengan nilai signifikasi $(0,181)$ yang lebih besar dibandingkan dengan 0,05 . Atau dengan kata lain, hipotesis ketiga (H3) penelitian ini tidak terdukung. Hal ini mengkonfirmasi hasil penelitian sebelumnya (Tariska, 2017), modal merupakan faktor penting untuk memulai usaha, namun tidak untuk mempertahankan kestabilan dalam pengembangan usaha. Pengembangan usaha merupakan langkah awal pertumbuhan usaha. Sehingga untuk menjaga perkembangan usaha tersebut, seorang wirausaha harus menjaga kualitas dan kuantitas produknya.

\section{SIMPULAN}

Pertumbuhan usaha pada UMKM dipengaruhi oleh karakteristik wirausaha dan lingkungan bisnis. Hal ini berarti bahwa ketika individu memiliki sebagaian dari karakteristik wirausaha, maka semakin besar pula pertumbuhan usaha. Seorang wirausaha minimal memiliki kemauan keras dan pantang menyerah, jujur dan bertanggung jawab, memiliki keyakinan yang kuat atas kekauataan pribadi, memiliki ketahanan fisik dan mental, bekerja keras, tekun dan ulet, serta memiliki pemikiran yang kreatif. Begitu juga, ketika seorang wirausaha mengenali lingkungan bisnis baik lingkungan internal dan lingkungan eksternal maka wirausaha semakin mudah menghadapi tantangan dalam menjalankan usahanya. Namun, pertumbuhan usaha tidak dipengaruhi oleh modal usaha. Modal usaha memang hal yang penting saat memulai usaha, akan tetapi tidak untuk mempertahankan kestabilan dalam pengembangan usaha. Sehingga untuk menjaga perkembangan usaha tersebut, maka seorang wirausaha harus dapat menjaga kualitas dan kuantitas produknya.

Penelitian ini memiliki nilai adjusted $R$ Square sebesar 27,4 persen. Sehingga, 72,6 persen variabel pertumbuhan usaha dipengaruhi oleh variabel lain di luar model. Sehingga, penelitian selanjutnya dapat menambahkan variabel independen, seperti strategi pemasaran.

\section{DAFTAR PUSTAKA}

Dwi, H. 2017. 3 Alasan Mengapa UMKM Penting bagi Perekonomian Indonesia. Https://Kumparan.Com. Retrieved from https://kumparan.com/hikman-dwi-r/3-peranpenting-umkm-penggerak-sektor-ekonomi-indonesia-di-tingkat-menengah-ke-bawah

Handoko, T. H. 2001. Manajemen. Yogyakarta: BPFE UGM.

Hantoro, S. 2005. Kiat Sukses Berwirausaha. Yogyakarta: Adicita Karya.

Inggarwati, K., \& Kaudin, A. 2010. Peranan Faktor-Faktor Individual Dalam Mengembangkan Usaha: Studi Kuantitatif pada Wirausaha Kecil di Salatiga. Integritas. Jurnal Manajemen Bisnis. 3(2): 185-202.

Jatmiko, R. 2004. Manajemen Stratejik. Retrieved from UMM Press

Kurniawan, I. S., \& Rinofah, R. 2016. Pengaruh lingkungan bisnis dan Strategi operasi terhadap kinerja operasional pada UKM kerajinan gerabah Yogyakarta. SOSIOHUMANIORA. Jurnal Ilmiah Ilmu Sosial Dan Humaniora. 2(2): 6-16.

Muhammad, S. 2000. Manajemen Stratejik: Konsep dan Kasus. Yogyakarta: UPP AMP YKPN.

Pamungkas, H. A., \& Hidayatulloh, A. 2019. Faktor Penentu Perkembangan UMKM Gerabah Kasongan Bantul Yogyakarta. InovasI: Jurnal Ekonomi, Keuangan Dan Manajemen. 15(1): 65-71.

Primus, J. 2017. Sepanjang 2017, Pemerintah Tambah Dana Bergulir untuk UMKM. 
Https://Money.Kompas.Com.

https://money.kompas.com/read/2017/01/09/171353826/sepanjang.2017.pemerintah.ta mbah.dana.bergulir.untuk.umkm

Purwanti, E. 2012. Pengaruh Karakteristik Wirausaha, Modal Usaha, Strategi Pemasaran Terhadap Perkembangan UMKM di Desa Dayaan Dan Kalikondo Salatiga. Jurnal Ilmiah Among Makarti. 5(9).

Riyanto, B. 2001. Pembelajaran Perusahaan. Yogyakarta: BPFE UGM.

Setyawati, E. C. N., Nugraha, H. S., \& Ainuddin, I. 2013. Karakteristik Kewirausahaan dan Lingkungan Bisnis Sebagai Faktor Penentu Pertumbuhan Usaha (Studi IKM di Sentra Kerajinan Rotan Amuntai Kab. Hulu Sungai Utara, Provinsi Kalimantan Selatan). Jurnal Administrasi Bisnis. 2(1): 41-50.

Tariska, D. 2017. Pengaruh Karakteristik Wirausaha, Modal Usaha dan Strategi Pemasaran Terhadap Pengembangan Usaha di Kampung Batik Ngasem di Daerah Istimewa Yogyakarta. Universitas Ahmad Dahlan.

Tempo.co. 2015. Rupiah Melemah, Omzet Perajin Perak Kotagede Anjlok. Https://Bisnis.Tempo.Co. Retrieved from https://bisnis.tempo.co/read/691895/rupiahmelemah-omzet-perajin-perak-kotagede-anjlok/full\&view $=$ ok

Undang-Undang Nomor 20 Tahun 2008.

Utari, T., \& Dewi, P. M. 2014. Pengaruh Modal, Tingkat Pendidikan dan Teknologi Terhadap Pendapatan Usaha Mikro Kecil dan Menengah (UMKM) di Kawasan Imam Bonjol Denpasar Barat. E-Jurnal Ekonomi Pembangunan Universitas Udayana.

Vries, K. de. 1997. The Entrepreneurial Personality, A Person at The Cross Roads. Journal of Management Studies. 14: 34-57.

Wiratmo, M. 2001. Pengantar Kewiraswataan. Yogyakarta: BPFE UGM. 